\title{
In memoriam Claude François Baudez. Mastering
} time

\section{OpenEdition \\ Journals}

Electronic version

URL: http://journals.openedition.org/jsa/15287

DOI: 10.4000/jsa.15287

ISSN: 1957-7842

Publisher

Société des américanistes

\section{Electronic reference}

«In memoriam Claude François Baudez. Mastering time », Journal de la Société des américanistes

[Online], Maya times | 2017, Online since 31 December 2017, connection on 24 September 2020. URL :

http://journals.openedition.org/jsa/15287 ; DOI : https://doi.org/10.4000/jsa.15287 


\title{
In memoriam Claude François Baudez
}

\author{
There is no doubt that the Mayas as well as representing time by means \\ of a path in space, also stage ceremonial walks at the end of each cycle. \\ This ritual aims to master time and, above all, to ensure continuity, \\ avoiding ruptures.
}

Claude F. Baudez, Une histoire de la religion des Mayas, Albin Michel, Paris, 2002, p. 330 (our translation).

\section{"Mastering time"}

The international conference organized by the Groupe d'enseignement et de recherche sur les Mayas et la Mésoamérique (GERM) and the musée du quai Branly, held a little more than a year after the death of our colleague and friend Claude F. Baudez, was dedicated to him. Another way of mastering time, through memory. We would like this opus to be the mark of our respect, admiration and friendship towards him.

The work of C. F. Baudez was vast and wide-reaching. He is an example for us all for his constant curiosity about everything that makes up Mesoamerica's history and culture, as well as the artistic legacy which it has contributed to humanity. His work continues to raise new questions and stimulate further studies. Through different lines of research, which combine archeology and iconology in particular, he was able to propose many inventive but prudent insights into Mayan religions - he insisted on the plural. With a constant appetite for discussion and an unfailing complicity with all those who investigate anthropology, history, art and, of course, archeology, Claude tirelessly nourished the three principles developed by the group of colleagues of which he was a kingpin: confrontation and collaboration between disciplines, comparison from near to far, teaching and share of knowledge. Throughout his life, he represented and communicated both the concerns and the joys that provide new insights in all scientific work. 